\title{
Correction to: The immunomodulatory functions and molecular mechanism of a new bursal heptapeptide (BP7) in immune responses and immature B cells
}

Xiu Li Feng ${ }^{1,2^{*}} \mathbb{0}$, Yang Zheng ${ }^{1,2}$, Man Man Zong ${ }^{1,2}$, Shan Shan Hao ${ }^{1,2}$, Guang Fang Zhou ${ }^{1,2}$, Rui Bing Cao ${ }^{1,2}$, Pu Yan Chen ${ }^{1,2}$ and Qing Tao Liu ${ }^{3^{*}}$

\section{Correction to: Vet Res (2019) 50:64}

https://doi.org/10.1186/s13567-019-0682-7

Following publication of the original article [1], the authors identified an error in the author name of Qing Tao Liu. The given names were erroneously transposed.

The incorrect author name is: Tao Qing Liu.

The correct author name is: Qing Tao Liu.

The author group has been updated above and the original article [1] has been corrected.

\section{Author details}

1 Key Laboratory of Animal Microbiology of China's Ministry of Agriculture, College of Veterinary Medicine, Nanjing Agricultural University, Nanjing 210095, China. ${ }^{2}$ MOE Joint International Research Laboratory of Animal Health and Food Safety, College of Veterinary Medicine, Nanjing Agricultural University, Nanjing 210095, China. ${ }^{3}$ Institute of Veterinary Medicine, Jiangsu Academy of Agricultural Sciences, Nanjing 210014, China.

Published online: 16 February 2021
Reference

1. Feng $X L$, Zheng Y, Zong MM, Hao SS, Zhou GF, Cao RB, Chen PY, Liu QT (2019) The immunomodulatory functions and molecular mechanism of a new bursal heptapeptide (BP7) in immune responses and immature $B$ cells. Vet Res 50:64. https://doi.org/10.1186/s13567-019-0682-7

\section{Publisher's Note}

Springer Nature remains neutral with regard to jurisdictional claims in published maps and institutional affiliations.

(c) The Author(s) 2021. This article is licensed under a Creative Commons Attribution 4.0 International License, which permits use, sharing, adaptation, distribution and reproduction in any medium or format, as long as you give appropriate credit to the original author(s) and the source, provide a link to the Creative Commons licence, and indicate if changes were made. The images or other third party material in this article are included in the article's Creative Commons licence, unless indicated otherwise in a credit line to the material. If material is not included in the article's Creative Commons licence and your intended use is not permitted by statutory regulation or exceeds the permitted use, you will need to obtain permission directly from the copyright holder. To view a copy of this licence, visit http://creativecommons.org/licenses/by/4.0/. The Creative Commons Public Domain Dedication waiver (http//creativecommons.org/publicdomain/zero/1.0/) applies to the data made available in this article, unless otherwise stated in a credit line to the data. 